\title{
Systematic Literature Review on the Relationship Between Islam and Organizational Performance
}

\section{Awang Moslem Awang Annuar, Jati Kasuma Ali}

To Link this Article: http://dx.doi.org/10.6007/IJARBSS/v11-i10/11176

DOI:10.6007/IJARBSS/v11-i10/11176

Received: 05 August 2021, Revised: 29 August 2021, Accepted: 21 September 2021

Published Online: 10 October 2021

In-Text Citation: (Annuar \& Ali, 2021)

To Cite this Article: Annuar, A. M. A., \& Ali, J. K. (2021). Systematic Literature Review on the Relationship Between Islam and Organizational Performance. International Journal of Academic Research in Business and Social Sciences, 11(10), 367-384.

\section{Copyright: (c) 2021 The Author(s)}

Published by Human Resource Management Academic Research Society (www.hrmars.com) This article is published under the Creative Commons Attribution (CC BY 4.0) license. Anyone may reproduce, distribute, translate and create derivative works of this article (for both commercial and non-commercial purposes), subject to full attribution to the original publication and authors. The full terms of this license may be seen at: http://creativecommons.org/licences/by/4.0/legalcode

Vol. 11, No. 10, 2021, Pg. 367 - 384

Full Terms \& Conditions of access and use can be found at http://hrmars.com/index.php/pages/detail/publication-ethics 


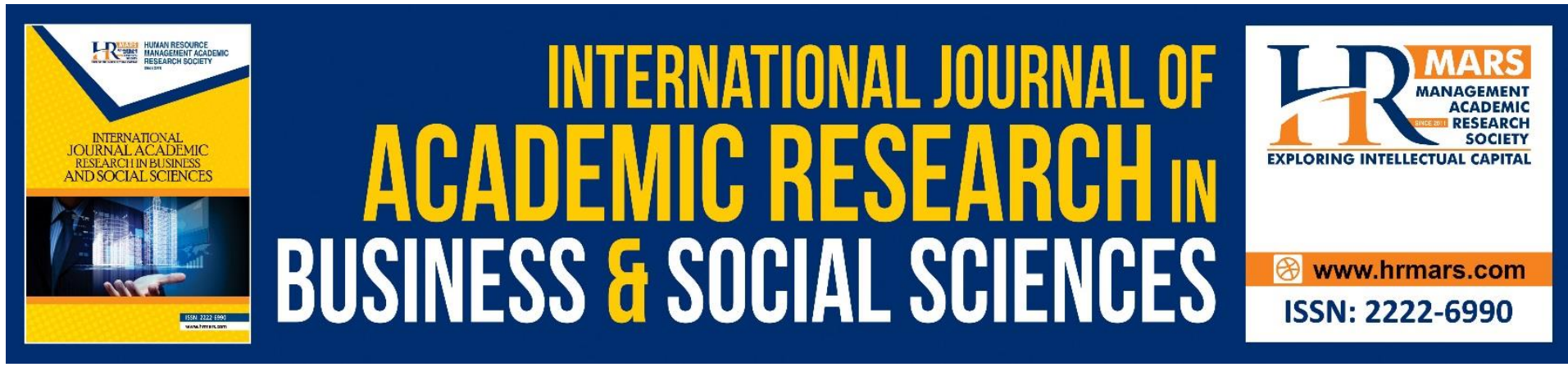

\title{
Systematic Literature Review on the Relationship Between Islam and Organizational Performance
}

\author{
Awang Moslem Awang Annuar \\ PhD Candidate, Universiti Teknologi MARA Shah Alam Malaysia \\ Email: azniaga@gmail.com \\ Dr. Jati Kasuma Ali
}

Associate Professor, Faculty of Business and Management Universiti Teknologi MARA Kota

Samarahan Malaysia

Email: jatikasuma@hotmail.com

\begin{abstract}
Since most research on Islam and organisational performance focus on specific area such as finance, human capital, banking services, waqaf, and entrepreneurship, this paper will attempt to study the overall relationship between Islam and organizational performance using systematic literature review without restricting its scope only on specific area of study, business or industry. This study is guided by adapting RepOrting standards for Systematic Evidence Syntheses (ROSES) review protocol. Based on thematic analysis, this study has identified five main themes - financial affairs, sharia-compliant organizations, Islamic human capital, social and network affairs, and environmental issues and tourism, and two subthemes - organizational roles, and Islamic banking. This research made several key contributions to the field's practical applications and body of knowledge, namely the role of Islam in organizational performance, the identification of the shortcomings of the implementation of sharia-compliant products and services. Future research should look further on how to improve the shortcomings that have been identified in this study, which include the products and services offered by Islamic financial institutions, and how these institutions can improve their services further to benefit their stakeholders even more.
\end{abstract}

Keywords: Islam, Organizational Performance, Business Performance, Entrepreneurial Performance, Organizational Growth

\section{Introduction}

The value systems of Islamic societies are divided into two categories: values pertaining to personal relationships with God, as well as values relating to communal cohesion (Carswell \& Rolland, 2007). Whatever work and economic activities Muslims engage in, they must be founded on fairness and benefit all of humanity, with an economic system built on the oneness of God as its foundation (Yousef, 2001). This should be applied across the board, be it in profit oriented organization, non-profit organization or social entrepreneurship setup. This overall success is knows as organizational performance. 
Islam wanted Muslims to excel in life Islam (Suprayinto, 2005), it encourages its followers to participate in business (Ramadani et al., 2015), and to become successful entrepreneurs, so that they can help the development of economy in their country (Faizal et al., 2013; Issoufou, 2019).

The majority of research on Islam and organizational performance focuses on specific areas such as finance, human resources, banking services, waqaf, and entrepreneurship, rather than the overall organization's performance. Because most systematic reviews focus on a single topic, this research will aim to undertake a systematic literature review on the relationship between Islam and organizational performance without limiting its scope to a single topic, business or industry.

To learn more about how Islam affect the overall performance of any organizations, this paper attempts to conduct a systematic literature review on this subject matter, guided by adapting RepOrting standards for Systematic Evidence Syntheses (ROSES) review protocol which will be explained further in the Methodology section in this paper.

\section{Identifying the Gap}

Even though there are studies conducted on Islam and organizational performance but mostly these studies are done on specific area such as on Islamic banking, human capital, Islamic finance, corporate governance, quality management, waqaf, and leadership. A thorough research has not found a systematic literature review on the relationship between Islam and the overall performance of organizations in profit oriented organization, non-profit organization and in social entrepreneurship setup.

By conducting a comprehensive literature review on the relationship between Islam and organizational performance, this paper will aim to add to the existing body of knowledge. A systematic literature review is a method for reviewing existing literature in a more systematic manner (Shaffril et al., 2020). It is the process of categorizing, choosing, and critically evaluating prior research in order to answer a certain formulates question (Dewey \& Drahota, 2016).

A systematic literature review is a clear and well-organized procedure in which a researcher or researchers uses several databases to perform their study, and this method may be duplicated by other scholars. It allows researchers to use a thorough search technique to solve a specific question (Xiao \& Watson, 2019).

The procedures of conducting and generating the end material will be detailed out in a systematic review paper, including the reporting standard utilized, databases and keywords used, article selection processes, quality evaluation, and discussions. Other researchers will be able to replicate the inquiry, validate the results, and investigate the generality using these systematic procedures.

The primary research question that guides this systematic review is "What is/are the relationship/s between Islam and organizational performance?" This research attempts to learn more about the relationship(s) between Islam and organizational performance and how Islam affect overall performance of any organization, be it profit and non-profit oriented organization or social entrepreneurship setup. 
This study offers several benefits to the practical aspect of organizational performance and to the body of knowledge. Through the understanding of the relationship between Islam and organizational performance, interested parties such as policy maker, entrepreneur, NGOs can apply Islamic values, principles and/or teachings in their organizations that will affect their performance.

\section{Methodology}

\section{The Review Protocol - RepOrting standards for Systematic Evidence Syntheses (ROSES)}

RepOrting standards for Systematic Evidence Syntheses in short ROSES review protocol see Figure 1 will be the systematic guide for this study. This review protocol is intended for systematic reviews and maps in the field of environmental management (Haddaway et al., 2018), it may, however, be used to a variety of different disciplines of study. One of the major goals of utilizing the ROSES review procedure in a systematic literature review is to guarantee that the researchers give accurate, relevant, and detailed information.

The authors began the RepOrting criteria for Systematic Evidence Syntheses review protocol by determining the suitable research topics for the review. The authors will next describe their systematic search approach, which will include the following three steps:

a. Identification,

b. Screening that consists of inclusion and exclusion criteria and

c. Eligibility of the resources (articles) for the review

The next stage in the ROSES process is to assess the quality of the articles that have been chosen. The authors will discuss their method for ensuring that the papers to be evaluated are of high quality. Finally, the authors will explain how they abstract the data for the review and how the abstracted data will be evaluated and validated, as this is a standard procedure in ROSES review protocol.

\section{Formulation of Research Question}

The first step is to develop a succinct and unambiguous research question that will guide the whole systematic review process. The following research question has been created since the goal of this study is to look at the link between any Islam and organizational performance What is/are the relationship/s between Islam and organizational performance?

\section{Systematic Searching Strategies}

To guarantee that the data used in this systematic literature review is relevant and appropriate for this study, systematic searching techniques are carried out by the researchers by going through the three primary processes: identification, screening with inclusion and exclusion criteria, and ultimately resource eligibility.

\section{Identification}

Identification is the initial stage in a systematic search strategy. It is a way of searching for synonyms, variations, and related phrases for the study's core keywords, which are Islam and organizational performance. The goal of identification is to provide the selected databases additional possibilities and alternatives for searching for more connected and relevant articles for the review. 
Okoli (2015), recommends that the keywords for this systematic literature review paper be determined based on the research topic, and the keywords from previous research, an online thesaurus, Scopus-suggested keywords, Web of Science-suggested keywords, and expertsuggested keywords all played a role in this identification process.

Two main journal databases are utilized for this study, there are Scopus and Web of Science (WoS). WoS is a large database with over 33,000 journals covering over 256 fields, including areas relevant to this research. It includes a comprehensive back file and citation data, established by Clarivate Analytics of over 100 years. The second database utilized in the review is Scopus. With approximately 22,800 journals from 5000 publishers worldwide, it is one of the largest abstracts and citation databases of peer-reviewed literature. Scopus covers a wide range of topics, including business, management, social science, technology, medical, the arts and humanities, and science.

Using different searching strategies such as phrase searching, Boolean operator, wild card, truncation, and field code functions, the authors were able to expand and alter the existing keywords and build a comprehensive search string on the two primary databases, Scopus and Web of Science.

The databases Scopus and Web of Science were chosen for a systematic literature review because of several advantages they offer, including vast resources and comprehensive collections of materials for scientific and systematic research, indexing of over 5000 publishers, advanced searching functions, quality control of articles, and multidisciplinary coverage (Gusenbauer, 2019; Martín-Martín et al., 2018). Using the search strings in Table 1 below, the authors were able to find 101 relevant publications from these two databases (Scopus and Web of Science).

Table 1. Search Strings for SCOPUS and Web of Science databases

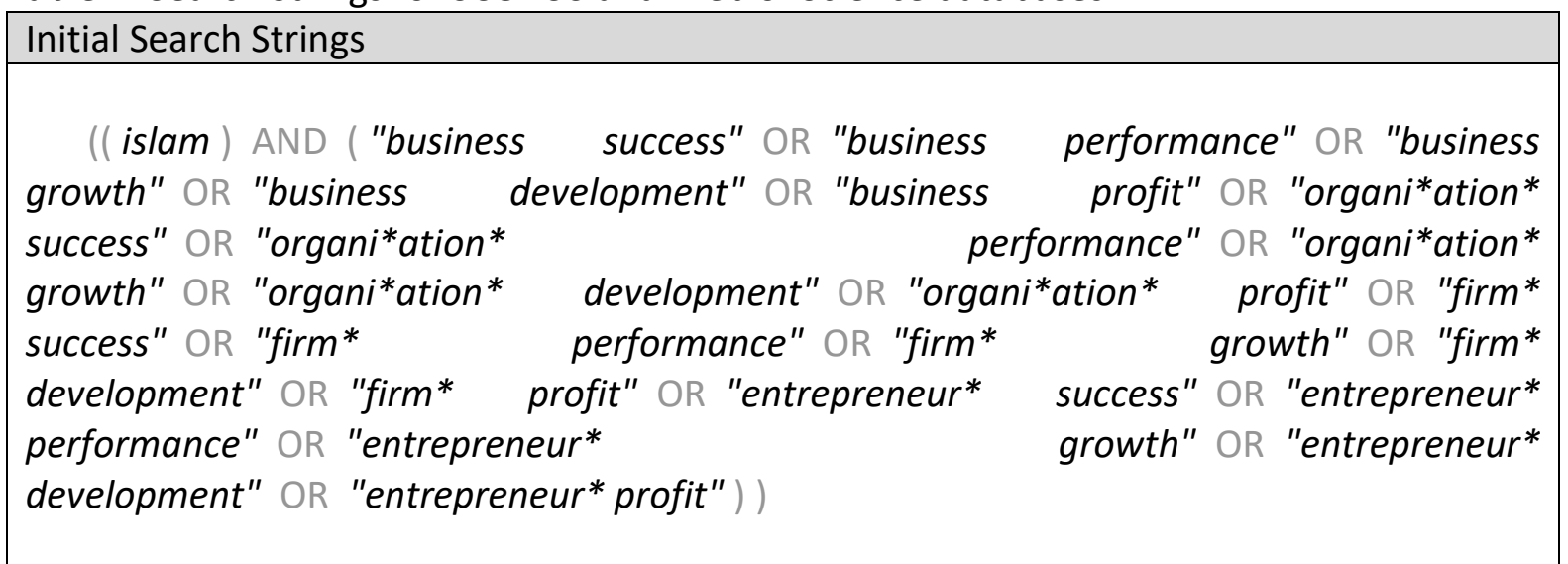

\section{Screening}

This study screened all 101 articles related using the criteria set in this study based on the research question for this systematic literature review. Okoli (2015), suggested that researchers should determine range of period that they able to review, because it is almost impossible for the researchers to review all the existing published articles. However, this research did not specify any time frame as the total number of records found without any specifying of any time frame were only 101 records. 
The inclusion criteria used in this study are only records in business and economy, and only publications in English are accepted and selected as shown in Table 2 below for both SCOPUS and Web of Science databases.

Table 2. Search strings with inclusion and exclusion criteria

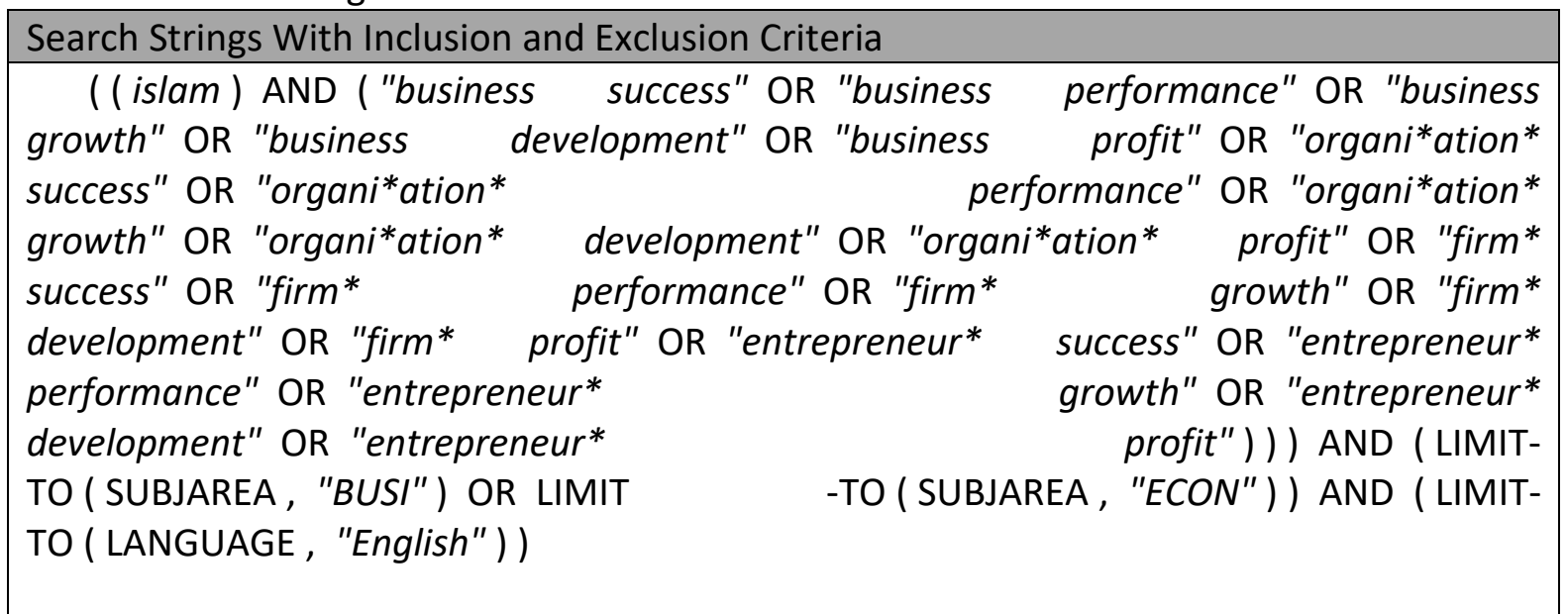

Only 56 records out of 101 fit the search criteria, and additional examination revealed that three SCOPUS records are unrelated to the study and eight WOS records are unrelated to the study, leaving 45 records to be downloaded for further analysis. Thirteen of the records are duplicates, while two are inaccessible. Only 30 records (articles) are chosen for the following stage of this systematic literature evaluation, which is the eligibility procedure.

\section{Eligibility}

By reading over the title and abstract of the articles, the authors manually examined the selected articles to verify that all of the remaining articles fit all of the criteria specified by them for the aim of addressing the research question. Four full-text records were omitted from the analysis because they focused on other topics - motivation, bankruptcy prediction model, ethical, and intellectual disclosure. This procedure yielded 26 items that were suitable for the quality assurance phase.

\section{Quality Appraisal}

The remaining 26 papers were examined by the authors to ensure that the quality of the articles met the study's objectives by answering the research question. Authors can rank the selected articles (Mohamed Shaffril et al., 2020), whereas they should divide the remaining articles into three quality categories - high, moderate, and low, and only the high and moderate quality articles should be reviewed (Petticrew \& Roberts, 2006).

The authors focused on the methodology of the papers and their relevance to the research topic in order to establish the quality rank, and only publications classified as moderate or high level by both authors would be included in the review.

Before determining whether or not to include or omit the articles for the review, the writers discussed any disagreements on the quality level of the articles. This method determined that 7 items were of high quality and 13 were of moderate or medium grade. As a result, out of the remaining 26 qualified records only 20 papers were considered for the review. 


\section{Data Abstraction and Analysis}

Integrative review technique is necessary to collect systematic conclusions from numerous research papers with distinct study designs such as qualitative, quantitative, and mix-methods with integrative data. The ideal approach to achieve this is to utilize qualitative or mixedmethod techniques, which allow the researcher to analyze and synthesize the article through iterative comparisons of primary data sources (Whittemore \& Knafl, 2005).

Data was abstracted from 20 articles selected at the ROSES reposting system's quality appraisal step based on the research topic. The authors thoroughly examined these 20 publications, with particular attention paid to the abstract, methodology, findings, and discussion of each paper.

Flemming et al., (2018), posited that thematic analysis is believed to be the best method for analyzing and synthesizing a mixed research design. Thematic method is the act of grouping comparable data into a certain category depending on the acquired information's topic. The authors created sub-themes (if any) from each topic to reflect comparable or related information or themes within the abstracted data (Braun \& Clarke, 2006).

The writers will find themes or patterns in the abstracted data of all the reviewed papers in the first phase of a thematic analysis. The writers discovered five main themes and two subthemes as a result of this process. Before adopting all of the themes, the writers doublechecked their correctness in relation to the topic of this study. The authors then went on to the next stage of this systematic literature review, which is synthesizing the themes, as stated in the Results section. 


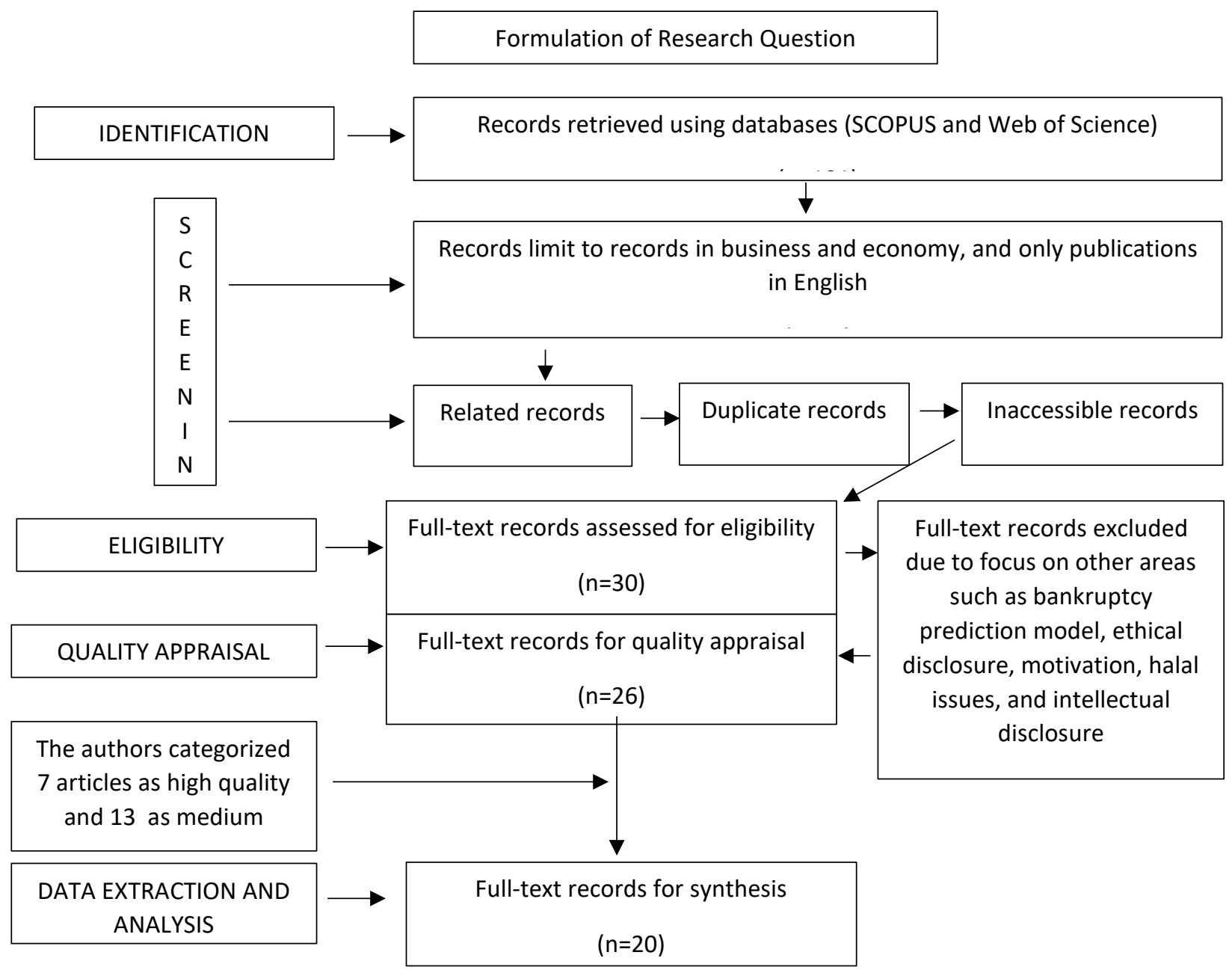

Figure 1 - Systematic Flow diagram (adapted from Shaffril et al (2019))

\section{Results}

\section{Background of Selected Articles}

Out of 20 records reviewed, 3 records discussed within Islamic financial affairs context looking at how shariah based organizations perform financially, 2 records discussed the roles of Islamic financial institutions, and 4 records relate Islamic banking and their performances, 5 records discussed on Islamic Human Capital and its relationship to performance, 4 records discussed on the social affairs in Islam, and how it relate to organizational performance, and 2 records discussed on how environmental issues and tourism relate to Islam and performance.

A thorough analysis of these 20 articles found 5 main themes and 2 sub themes by the authors that answer the research question. These themes and sub-themes are:

1. Financial Affairs

\section{- Organizational Roles}

- Islamic Banking

2. Sharia-compliant Organizations

3. Islamic Human Capital

4. Social Network and Affairs 


\section{Environmental and Tourism}

\section{The Theme}

\section{Financial Affairs}

\section{Organizational Roles}

The gap between the theoretical perspective and the real application of profit-and-losssharing (PLS) forms of finance is increasing to worrying levels, based on accessible bank and national statistics is due to the majority of Islamic financial institutions' (IFIs) unfavourable attitude and lack of adequate infrastructure, and their reluctance to accommodate entrepreneurship through the actual application of PLS tools (Kayed, 2012).

While PLS models dominate the theoretical literature on Islamic finance, and the majority of mainstream Muslim scholars and financial authorities view PLS models as attractive financial alternatives and practical development instruments, the reality of Islamic finance portrays a different picture. This study highlighted the need of IFIs adhering to their own charters and taking the lead in development, in order to achieve al-Shariah goals (maqasid al Shariah).

The adoption of Islamic microfinancing, which was preceded by a microenterprise selection process and was also supported by business control, an incentive system, and the development of excellent relationships, was beneficial in establishing microenterprises and increasing household income. However, in order to increase the efficiency of Islamic microfinance, an integrated program is still required (Hadisumarto \& Ismail, 2010).

Micro-enterprise development necessitates not only the supply of interest-free finance, but also the provision of additional services. Spiritual growth, particularly via internalizing Islamic moral principles in an entrepreneur's awareness, is also required for a comprehensive approach to micro-enterprise development and poverty reduction.

Furthermore, poverty reduction will be successful if Islamic funding is used in a variety of fields, and the government participates. This study demonstrates how, from an Islamic perspective, spiritual growth is essential for enhancing finance efficacy.

\section{Banking}

The macroeconomic parameters of Gross Domestic Product (GDP), Gross Domestic Product Growth (GDPD), and IR (Inflation Rate) are found to have a substantial and positive association with Return On Asset (ROA). Furthermore, the financial crisis and Islamic banking performance in emerging nations have a substantial negative relationship (Mohammed \& Muhammed, 2017)

When success is evaluated by the Zakat ratio, however, the current analysis finds no indication of a link between macroeconomic issues and performance, including the legal system and the financial crisis. When seen through the lens of conventional banking, the finding shows that the financial crisis had an influence on the performance of Islamic banks in developing nations.

According to Islamic performance metrics, not just the financial crisis, but also macro issues, had no impact on Islamic banking performance. However, Hasan \& Dridi (2011), posited that 
there is insufficient data in their study to draw any conclusions about the influence of the financial crisis on Islamic banking in an emerging economy.

They further suggested that the policymakers should take note that Islamic banking is not only safer than traditional banking, but it can also protect the national economy during times of crisis. It also exposes the inadequacies of traditional banking, particularly in light of recent economic instability, as sharia-based banking may be able to help developing nations with emerging markets defend themselves. However, further study is needed to confirm these findings, such as looking at different sectors.

The success of an Islamic bank - as a firm founded on Islamic principles - is influenced not only by quantitative internal factors (such as financial ratios), but also by qualitative internal variables such as managerial characteristics despites the existence of sharia compliance committee (Ghayad, 2008).

Furthermore, due of the differences in the degree of objectives, the performance of an Islamic bank and a normal bank should not be compared. To ensure greater monitoring and consultation, the sharia member must have a financial and business qualification.

The study also pointed out that sharia board members were a significant impediment for Islamic bank directors. The sharia board members and the directors did not speak the same language. In contrast to the directors in sharia, the members of the sharia board were not particularly skilled in subjects other than sharia.

According to the Generalized Method of Moments estimate, Shariah Supervisory Board features (size, cross-membership, PhD qualification, reputation, experience, and total change in the SSB composition) have substantial influence on performance (Nomran et al., 2020). The study supports the necessity of having more academics with a PhD in order to improve the IBs' performance. According to the data, PhD degrees are required for SSB scholars of Malaysian IBs, however there is a demand for SSB scholars with PhDs in other areas such as accounting and finance. Similarly, the data supports the notion that respected SSB academics are critical for IBs since they reflect industry knowledge and, as a result, boost IB performance.

\section{Sharia-compliant Organization}

Sharia is a collection of Islamic rules for personal and communal behavior. If a company adheres to Islamic ideals, it is classified as a sharia organization, and sharia-compliant organizations outperform the non-sharia compliant organizations. Sharia positioning may boost performance, and they provide actual proof that the ethical firm has a substantial impact on outcomes (Gati et al., 2020).

In the study on the impacts of diversity within Islam among top-level management of companies on financial performance of listed companies in Malaysia, Hassan \& Marimuthu (2018), stated that despite the fact that many businesses want to be more socially diverse, the value of diversity in terms of organizational performance is still debateable.

Sharia-compliant firms are subject to constraints whereas non-shariah compliant firms are not, therefore the impact of oil price volatility is greater on sharia-compliant firms than on 
non-shariah compliant firms. As a result, non-sharia compliant firms are better equipped to deal with short-term uncertainty (Bugshan et al., 2021).

Their study showed that sharia-compliant businesses have a larger risk of bankruptcy than non-sharia-compliant firms due to significant oil price volatility, and positive and negative oil price shocks have unequal impacts on company performance. Therefore sharia-compliant instruments should be developed to compete with traditional instruments in order to assist sharia-compliant businesses in dealing with uncertainty.

\section{Islamic Human Capital}

Bhaskaran et al (2021) who studied if Fortune 100 top businesses have higher market performance and capitalization in relation to their workers' happiness as a key contributor to greater performance as compared to other companies, found that organizational performance is contributed by satisfied employees. According to them, the top ten employers with the most workers, as well as their number of times listed in Fortune's best businesses, are in accordance with and consistent with the idea of CSR in Islam, which covers legal, economic, ethical, and charitable obligations as posited by (Maruf, 2013).

Islamic human resource practices and company performance have some positive and substantial relationships. Essentially, just one Islamic human resource technique, that of training and development, is favorably and significantly connected to organizational performance (Azmi, 2015).

To improve organizational effectiveness, Islamic organizations should stress this practice. Islamic human resource practices place a premium on instilling Islamic ideals in universally accepted processes. As a result of its execution, the society will be bettered in terms of psychology, morality, and spirituality. Not only in organizations, but also in society, cooperation, collaboration, and harmony might be steady.

Sharia compliance and Tawhid realization are significant variables in recognizing Muslim entrepreneurship opportunities (Sidek et al., 2015). They found five Islamic spiritual concepts in which Islamic beliefs influence the sourcing of business opportunities. These concepts are fardhu kifayah, da'wah, amānah, barakah, and 'ibadah that drove the opportunity discovery and opportunity creation processes, respectively, through the discovery of missing items or services in the marketplace and discontent with the present state.

There is a substantial positive link between Islamic entrepreneurial mind programming and entrepreneurial performance, which is mediated by entrepreneurial motivation. The findings of the research show that Islamic entrepreneurial mind programming is an essential element among other variables influencing entrepreneurial motivation (Abdullah et al., 2015).

\section{Social Network and Affairs}

Spirituality does in fact fuel members' commitment to the network, and spirituality has a particular impact on members' contributions to and demands on the network (Kurt et al., 2020). Members who view their shared religion as an entry point into the network appear to benefit from both tangible and intangible network resources, while members who treat their 
network membership as an extension of their spiritual practice appear to benefit from both tangible and intangible network resources.

The impact of Islam and Javanese aristocratic authority were other factors in the emergence of social entrepreneurship (Idris \& Hati, 2013). In the context of Indonesia's post-colonial socio-economic environment, this research suggested that the country's current social entrepreneurship growth is likely to be influenced by three main factors - indigenous groups' perceptions of economic empowerment as a result of social entrepreneurship, social enterprises' Islamic identity, and social activism.If appropriately identified and understood, Islamic principles and culture may help organizations adapt and develop (Ali, 1996).

The heart of Islamic social entrepreneurship is based on the hadith "Khairunnas anfa'uhum linnas," which holds that the most valued individual is the one who benefits others the greatest (Mulyaningsih \& Ramadani, 2016). Every Muslim entrepreneur should divide their efforts into two roles as a person on Allah's responsibility.

First, human development (habbluminannas) indicates that Muslim entrepreneurs should emphasize a dual-construct purpose in all human-related operations. Second, spiritual growth (habbluminallah) implies that humans were created by Allah to serve and adore only Him. Every good deed done for human beings is meant to be done in accordance with Allah's commandments and in order to maintain a good relationship with Allah. To put it another way, habluminannas is used to achieve habluminallah, and both are correct and cannot be contested.

\section{Environmental and Tourism}

Environmental marketing, as well as operational and economic success, are all linked to environmental orientation. Nonetheless, owing to "greenwashing" tactics, environmental marketing has no significant impact on commercial performance (Hari Adi \& Adawiyah, 2018).

The connection between environmental orientation and environmental marketing strategies appears to be moderated by religiosity. It is critical to instil religious beliefs in society, particularly among entrepreneurs, as moral guides for enhancing ethical behavior in the workplace.

Islamic tourism has the potential to become a significant part of the tourism sector. Given the current worldwide trend, Islamic tourism appears to be on the verge of a bright future (ElGohary \& Eid, 2014). Islam's expression in the context of tourism, arguing for its potential as a key component of a growing worldwide Islamic tourist sector. While "halal friendly" tourism recognizes Muslims' freedom to follow their faith, Islamic tourism has the ability to foster intercultural discussion and tolerance. Therefore, this development showed that Islam plays a vital role in the performance of tourism related organizations.

\section{Discussion}

Five themes and two sub-themes emerged from the thematic analyses in this systematic review to explain the relationship between Islam and organizational performance. Their contributions to the body of knowledge of Islamic organizational performance systematic literature review and their applications will be discussed in this section. 
Organizations that follow sharia procedures outperform their non-sharia compliant counterparts (Gati et al., 2020). However, the influence of Islam's diversity on organizational success is still up for debate (Hassan \& Marimuthu, 2018).

Because sharia-compliance businesses have limitations whereas non-compliant businesses do not, the impact of oil price volatility is larger on sharia-compliant businesses than on nonsharia compliant businesses (Bugshan et al., 2021). As a result, additional Islam-compliant instruments should be developed to compete with existing instruments in order to help sharia-compliant firms manage uncertainty.

The same thing can be said to Islamic microfinancing. Even though it has proven to be effective in developing microbusinesses and boosting household income, it still requires an integrated program to maximize its effectiveness (Hadisumarto \& Ismail, 2010).

The financial crisis and the performance of Islamic banking in emerging markets have a significant unfavourable connection (Mohammed \& Muhammed, 2017). However, there is inadequate evidence to make any judgments regarding the financial crisis' impact on Islamic banking in a developing economy (Hasan \& Dridi, 2011).

Islamic banking is not only safer than regular banking, but it can also defend the national economy during times of crisis, according to officials. Sharia-based banking may be able to assist developing countries with emerging markets in their defence. Nevertheless, further research is needed to validate these findings, such as examining other industries.

Despite the establishment of a sharia compliance committee, qualitative internal variables such as management qualities and quantitative internal factors such as financial ratios both contributed to the success of an Islamic bank (Ghayad, 2008).

Size, cross-membership, PhD qualification, reputation, experience, and the overall makeup of the Shariah Supervisory Board (SSB) all have a significant impact on success (Nomran et al., 2020), and in order to increase the performance of Islamic banks, more academics with PhD are needed.

Islamic CSR encourages brotherhood and justice to balance employee rights and enhance coherence between self-interest and charity, resulting in pleased workers who contributed to corporate success (Bhaskaran et al., 2021). In Islam, corporate social responsibility (CSR) encompasses legal, economic, ethical, and philanthropic responsibilities as posited by (Maruf, 2013).

Positive and significant correlation existed between Islamic human resource practices and corporate performance. In essence, just one Islamic human resource method, training and development, is positively and substantially associated with organizational success (Azmi, 2015).

Islamic entrepreneurial mind training and entrepreneurial performance have a significant beneficial link that is mediated by entrepreneurial motivation (Abdullah et al., 2015). While 
Shariah compliance and Tawhid realization are important factors in identifying Muslim business possibilities, they are not the only ones (Sidek et al., 2015).

More research is needed to have a better understanding of the role of Islam at work, particularly how Islamic beliefs, culture, values, and norms are applied in practice and their effects on the workplace and overall organizational performance (Budhwar \& Mellahi, 2010).

Muslim entrepreneurs come together to support one another and benefit from the network that has grown out from Muslim brotherhood and sisterhood. The identity of social businesses, which is at the core of Islamic social entrepreneurship, led to the expansion of social entrepreneurship is based on the hadith "Khairunnas anfa'uhum linnas", and Islamic principles and culture may help organizations to adapt and develop.

Religiosity appears to attenuate the relationship between environmental orientation and environmental marketing strategies. Religious values must be instilled in society, especially among entrepreneurs, as moral guidelines for improving ethical behavior in business.

Islamic tourism has the potential to grow into a large component of the tourism industry. While "halal-friendly" tourism respects Muslims' right to practice their religion, Islamic tourism has the potential to promote intercultural dialogue and tolerance. As a result of this development, Islam has become increasingly important in the performance of tourismrelated organizations.

\section{Conclusion and Recommendations}

Studies have shown that Islam have a positive effect on the performance of organization through its principles, values and teachings. Studies have also shown that sharia-compliant organizations outperform non-sharia compliant organizations. However due to shariacompliant firms are subject to constraints whereas non-sharia compliant firms are not, the impact of oil price volatility is greater on sharia-compliant firms. Therefore sharia-compliant instruments should be developed more to compete with traditional instruments to assist shariah-compliant businesses in dealing with uncertainty.

Even though the adoption of Islamic microfinancing, was beneficial in establishing microenterprises and increasing household income, an integrated program is still required to increase its efficiency. Islamic financial institutions (IFIs) should accommodate the entrepreneur's community more to provide adequate infrastructure and variety of financial instruments to foster more growth and to promote Islamic business practice further especially among Muslim entrepreneurs and businesses.

Financial crisis and Islamic banking performance in emerging nations have a substantial negative relationship. It is not only safer than traditional banking, but it also has the ability to protect the national economy during times of crisis. However, there is not enough information to make any judgments regarding the impact of the financial crisis on Islamic banking in emerging markets. As a result, more research is needed to confirm these findings, such as looking at different sectors. 
To conclude Islam have a positive effect on organizational performance and more effort should be taken by Muslims to include the true values, teaching and principles of Islam in their day to day activities and more sharia-compliant products and services are developed to improve the current short coming of the current sharia-compliant products and services which are available in the market today.

Muslims' concerned on financial affairs, shariah-based business practices, human capital and social affairs, environmental issues, and halal tourism can be seen as a positive signal to Muslim business community and organizations that great potentials are in front of them resulted from the teaching of Islam, therefore capitalizing on these opportunities and ibadah (serving Allah) at the same time will bring much success not just to their organizations but humanity.

Finally research also shown that more studies are needed to get a greater knowledge of the role Islam plays in the organization, especially how Islamic beliefs, culture, values, and norms are employed in practice and their consequences on the working environment and overall organizational performance, since if corporate organizations connect themselves with real religious practices, they may avoid, avert, or at the very least mitigate the huge losses generated by scandals produced by a lack of religious consciousness as posited by (Annuar \& Ali, 2021).

\section{Contextual Contribution}

Even though Islam plays a vital role in organizational performance, more things need to be done to improve the shortcomings of its implementation. These shortcomings are in the form of in adequate sharia-compliant products and services to handle different issues or new market issues, the seriousness of the practitioners to embrace the true teachings of Islam in their work and organizations, and the role of policy makers to take the necessary measures to ensure to make Islam as the catalyst for the organizational performance.

\section{References}

Azmi, A. G. I. (2015). Islamic human resource practices and organizational performance: Some findings in a developing country. Journal of Islamic Accounting and Business Research, 6(1), 2-18. https://doi.org/10.1108/JIABR-02-2012-0010

Mohammed, Al-N. S. A. S., \& Muhammed, J. D. (2017). Financial crisis, legal origin, economic status and multi-bank performance indicators. Journal of Applied Accounting Research, 18(2), 208-222. https://doi.org/10.1108/jaar-07-2014-0065

Ali, A. J. (1996). Organizational development in the Arab world. Journal of Management Development, 15(5), 4-21. https://doi.org/10.1007/978-1-4020-5614-7_2462

Annuar, A. M. A., \& Ali, J. K. (2021). Systematic Literature Review on the Relationship between Religion and Business Success Systematic Literature Review on the Relationship between Religion and Business Success. Nternational Journal of Academic Research in Business and Social Sciences, 11(7), 529-546. https://doi.org/10.6007/IJARBSS/v11-i7/10194

Annuar, A. M. A., \& Ali, J. K. (2021). Systematic Literature Review on the Relationship Between Islam and Organizational Performance. International Journal of Academic Research in Business and Social Sciences, 11(10), 367-383.

Bhaskaran, R. K., Ting, I. W. K., Azizan, N. A., \& Yelubolu, K. V. (2021). Determinants and market performance of Fortune 100 best companies: evidence from Islamic perspective. 
Journal of Islamic Accounting and Business Research, 12(1), 44-59. https://doi.org/10.1108/JIABR-12-2019-0248

Braun, V., \& Clarke, V. (2006). Using thematic analysis in psychology. Qualitative Research in Psychology, 3(2), 77-101. https://doi.org/10.1191/1478088706qp063oa

Budhwar, P. S., \& Mellahi, K. (2010). Introduction: Islam and human resource management. Personnel Review, 39(6), 685-691. https://doi.org/10.1108/00483481011075558

Bugshan, A., Bakry, W., \& Li, Y. (2021). Oil price volatility and firm profitability: an empirical analysis of Shariah-compliant and non-Shariah-compliant firms. International Journal of Emerging Markets. https://doi.org/10.1108/IJOEM-10-2020-1288

Carswell, P., \& Rolland, D. (2007). Religion and entrepreneurship in New Zealand. Journal of Enterprising Communities: People and Places in the Global Economy, 1(2), 162-174. https://doi.org/10.1108/17506200710752584

Dewey, A., \& Drahota, A. (2016). Introduction to systematic reviews: online learning module.

El-Gohary, H., \& Eid, R. (2014). Emerging research on Islamic marketing and tourism in the global economy. Emerging Research on Islamic Marketing and Tourism in the Global Economy, June, 1-311. https://doi.org/10.4018/978-1-4666-6272-8

Faizal, P. R. M., Ridhwan, A. A. M., \& Kalsom, A. W. (2013). The Entrepreneurs Characteristic from al-Quran and al-Hadis. International Journal of Trade, Economics and Finance, 4(4), 191-196. https://doi.org/10.7763/ijtef.2013.v4.284

Flemming, K., Booth, A., Garside, R., Tunçalp, Ö., \& Noyes, J. (2018). Qualitative evidence synthesis for complex interventions and guideline development: clarification of the purpose, designs and relevant methods. BMJ Global Health, 4(Suppl 1), e000882. https://doi.org/10.1136/bmjgh-2018-000882

Gati, V., Nasih, M., Agustia, D., \& Harymawan, I. (2020). Islamic index, independent commissioner and firm performance. Cogent Business and Management, 7(1). https://doi.org/10.1080/23311975.2020.1824440

Ghayad, R. (2008). Corporate governance and the global performance of Islamic banks. Humanomics, 24(3), 207-216. https://doi.org/10.1108/08288660810899368

Gusenbauer, M. (2019). Google Scholar to overshadow them all? Comparing the sizes of 12 academic search engines and bibliographic databases. In Scientometrics (Vol. 118, Issue 1). Springer International Publishing. https://doi.org/10.1007/s11192-018-2958-5

Haddaway, N. R., Macura, B., Whaley, P., \& Pullin, A. S. (2018). ROSES Reporting standards for Systematic Evidence Syntheses: Pro forma, flow-diagram and descriptive summary of the plan and conduct of environmental systematic reviews and systematic maps. Environmental Evidence, 7(1), 4-11. https://doi.org/10.1186/s13750-018-0121-7

Hari Adi, P., \& Adawiyah, W. R. (2018). The impact of religiosity, environmental marketing orientation and practices on performance: A case of Muslim entrepreneurs in Indonesia. Journal of Islamic Marketing, 9(4), 841-862. https://doi.org/10.1108/JIMA-09-20160067

Hasan, M., \& Dridi, J. (2011). The effects of the global crisis on Islamic and conventional banks: A comparative study: International Monetary Fund.

Hassan, R., \& Marimuthu, M. (2018). Contextualizing comprehensive board diversity and firm financial performance: Integrating market, management and shareholder's perspective. Journal of Management and Organization, 24(5), 634-678.

https://doi.org/10.1017/jmo.2018.10

Idris, A., \& Hati, H. R. (2013). Social Entrepreneurship in Indonesia: Lessons from the Past. Journal of Social Entrepreneurship, 4(3), 277-301. 
https://doi.org/10.1080/19420676.2013.820778

Issoufou, C. (2019). Creation of young entrepreneurs as resources of economic development and alleviation of poverty in muslim countries: An Islamic approach. Humanities and Social Sciences Reviews, 7(5), 1060-1064. https://doi.org/10.18510/hssr.2019.75141

Kayed, R. N. (2012). The entrepreneurial role of profit-and-loss sharing modes of finance: theory and practice. International Journal of Islamic and Middle Eastern Finance and Management, 5(3), 203-228. https://doi.org/10.1108/17538391211255205

Kurt, Y., Sinkovics, N., Sinkovics, R. R., \& Yamin, M. (2020). The role of spirituality in Islamic business networks: The case of internationalizing Turkish SMEs. Journal of World Business, 55(1), 101034. https://doi.org/10.1016/j.jwb.2019.101034

Martín-Martín, A., Orduna-Malea, E., Thelwall, M., \& López-Cózar, D. E. (2018). Google Scholar, Web of Science, and Scopus: A systematic comparison of citations in 252 subject categories. Journal of Informetrics, 12(4), 1160-1177.

https://doi.org/10.1016/j.joi.2018.09.002

Maruf, A. A. (2013). Corporate Social Responsibility and Corporate Image. Transnational Journal of Science and Technology, 3(8), 29-49.

Hadisumarto, M. C. W., \& Ismail, A. G. (2010). Improving the effectiveness of Islamic microfinancing: Learning from BMT experience. Humanomics, 26(1), 65-75. https://doi.org/10.1108/08288661011025002

Abdullah, M. A., Zulkarnain, \& Md. Aftab. (2015). Effects of Islamic entrepreneurship mind programming on entrepreneurial performance through entrepreneurial motivation. International Journal of Business and Globalisation, 15(3), 294.

Shaffril, M. H. A., Ahmad, N., Samsuddin, S. F., Samah, A. A., \& Hamdan, M. E. (2020). Systematic literature review on adaptation towards climate change impacts among indigenous people in the Asia Pacific regions. Journal of Cleaner Production, 258, 120595. https://doi.org/10.1016/j.jclepro.2020.120595

Shaffril, M. H. A., Samah, A. A., Samsuddin, S. F., \& Ali, Z. (2019). Mirror-mirror on the wall, what climate change adaptation strategies are practiced by the Asian's fishermen of all? Journal of Cleaner Production, 232, 104-117.

https://doi.org/10.1016/j.jclepro.2019.05.262

Mulyaningsih, H. D., \& Ramadani, V. (2016). Social Entrepreneurship in an Islamic Context. Entrepreneurship and Management in an Islamic Context, 143-158. https://doi.org/10.1007/978-3-319-39679-8

Nomran, N. M., Haron, R., \& Hassan, R. (2020). Shari'Ah Supervisory Board Characteristics Effects on Islamic Banks' Performance: Evidence from Malaysia. SSRN Electronic Journal. https://doi.org/10.2139/ssrn.3598723

Okoli, C. (2015). A guide to conducting a standalone systematic literature review. Communications of the Association for Information Systems, 37(1), 879-910. https://doi.org/10.17705/1cais.03743

Petticrew, M., \& Roberts, H. (2006). M. Petticrew and H. Roberts. Systematic Reviews in the Social Sciences: A Practical Guide . Oxford: Blackwell 2006. 352 pp. ISBN 1405121106. f29.99. Counselling and Psychotherapy Research, 6(4), 304-305.

https://doi.org/10.1080/14733140600986250

Ramadani, V., Ratten, V., Dana, L. P., \& Tahiri, S. (2015). The context of Islamic entrepreneurship and business: concept, principles and perspectives. International Journal of Business and Globalisation, 15(January), 244-261.

https://doi.org/10.1504/IJBG.2015.071906 
Sidek, F., Pavlovich, K., \& Gibb, J. (2015). An Islamic perspective on entrepreneurial opportunity recognition. International Journal of Entrepreneurship and Small Business, 25(4), 395-413. https://doi.org/10.1504/IJESB.2015.070215

Suprayinto, E. (2005). Ekonomi Islam, Pendekatan Ekonomi Makro Islam dan Konvensional. Graha Ilmu.

Whittemore, R., \& Knafl, K. (2005). The integrative review: updated methodology. Nursing Research, 9(1 SUPPL), 11-21. https://doi.org/10.1016/j.pmn.2007.11.006

Xiao, Y., \& Watson, M. (2019). Guidance on Conducting a Systematic Literature Review. Journal of Planning Education and Research, 39(1), 93-112. https://doi.org/10.1177/0739456X17723971

Yousef, D. A. (2001). Islamic Work Ethic. Handbook of Research on Islamic Business Ethics, 30(1958), 152-169. https://doi.org/10.4337/9781781009451.00027 